\title{
The very special profile of the military student
}

\begin{abstract}
In the Turkish Armed Forces the bulk of the man-power are the conscripts who are plain soldiers/ privates. The re-enlisted corporals come next. The hard-core consists of the petty-officers and the commissioned rank holders, i.e. officers, both categories forming the real professional cadres. They are raised in military schools. The military students constitute a precious human resource for the state, defense being an indispensable protective measure for probable turbulent times. The formation of the cadet profile emerges through formal training and education as well as informal influences deriving from their own interaction among themselves. In addition to such internal shaping forces, external factors defined by the country's socio-cultural and economic situation also come into play.
\end{abstract}

Volume I Issue 3 - 2017

\author{
Sinan Çaya \\ Istinye University, Turkey
}

Correspondence: Sinan Çaya, Istinye University, Turkey, Email sinan.caya@gmail.com

Received: April 05, 2017| Published: May 29, 2017

Keywords: cadet, student, military, education, training

\section{Introduction}

For the Republic of Turkey, the Armed Forces represent one of the most important establishments. It is in fact, much more than a mere classical defense institution. Indeed, their peace-time missions are also important as a contribution to development. The Turkish Armed Forces manages such peace time functions with the utmost success. Firstly for a conscript (who represents the basic man-power), the entire period of service is like attending a public education program designed for adults. Then come activities like offering help in natural disasters, upholding the economy by technical expertise of retirees and contribution to social development and improvement ${ }^{1}$ as role models.

Today's cadets are the commanders of tomorrow and the traditional schooling style of the burgeoning hard core keeps determining the profile of the future command. Of course martial values are indoctrinated officially through the curriculum, on one hand. But on the other hand, the informal interaction of the cadets with one another is at least as influential as the formally impregnated values and attitudes; and this sometimes happens in opposition to the formal efforts. Moreover, external environmental factors beyond the military schools themselves cannot be denied in their intervening effects, either (Figure 1).

\section{Turkish cadets-their background}

The social milieu from which non-commissioned-officer (petty officers / warrant officers) schools find their roots, are much more modest than those from which officer schools are fed. The latter, however is itself not very high as far as its location among the social stratification is concerned. When it comes to talk about the background of all cadets; cadets an important point to consider is the fact that Turkey is a young-populated country in rapid, constant transition. This change is more conspicuous since 1950s. As the bigger society changes for the better, the social make-up of the pool of professionals gets also altered, continuously.

${ }^{1}$ After a terrible earthquake swept the city of Erzincan in 1939, a military school was founded there, as a compensation for the grieved people. Erzincan Military Lycée, like many other military institutions, did a lot of good to the region until mid-1960s, at which date it got abolished (Documents, books, lab equipment and other properties were transferred to the military lycée in Istanbul).

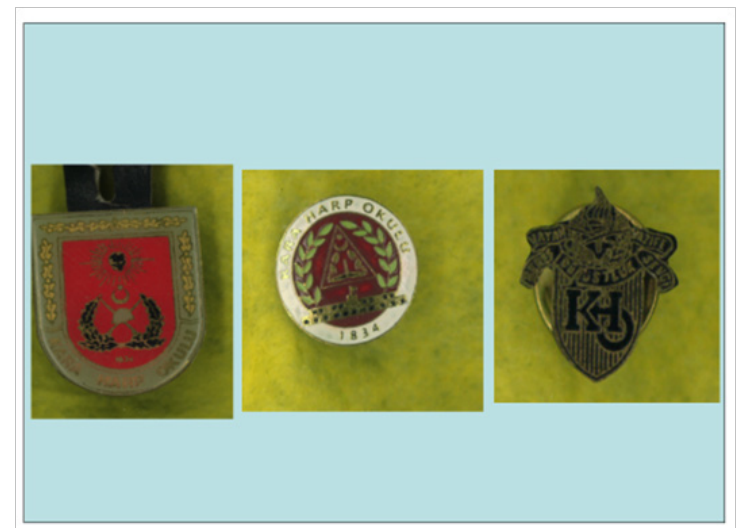

Figure I The Amblem \& Two Rosettes the War College.

Statistics [from the Second Development Plan] display that citycenters increase in size and number on one hand while people tend to choose to live in big cities on the other hand. ${ }^{1}$ The fact that even for the moment, two-thirds of the population of İstanbul Turkey's biggest city is made up from "those who were born elsewhere"; is the hardest evidence that İstanbul is invaded by "provincials". No doubt, this invasion will continue with a growing acceleration in the years to follow. The funny thing is, the affirmation of "being a İstanbulite" is also very common among those who had moved to İstanbul from outside. $^{2}$

Nevertheless many other urban norms are strongly resisted. No wonder for that. The driving force of the urbanization is basically migration into the cities, rather than a natural evolution. In a sense, this means that many traditional norms and values (even some bloodfeuds included) are simply "transplanted" onto the social and cultural setting of the big cities, instead of falling into oblivion. In fact, while up to 1950 s, the well-established, distinct urban culture could dilute and buffer the incremental intrusion of rural habits and assert itself as a role-model for the new-comers; nowadays; the new-comers attempt to dominate the city-dwellers and make them resemble themselves. Paradoxically, as Erkal ${ }^{3}$ points out, one of the reasons why people leave the rural areas and arrive in cities is the purpose of joining the already gone compatriots! So, we can see neighborhoods of compatriots (Landsmann) growing in big cities. But whatever course urbanization follows, confrontation with the social reality 
of the city, obliges the formerly-rural new settlers do take up some modern norms. Moreover, one conspicuous gain of urbanization is better formal education, which is reflected on to the education level of the conscripts directly. As the immediate subjects of their leaders (professionals), the better educated and more urbanized conscripts in turn affect the behavior patterns of the leaders ${ }^{\left(2^{*}\right)}$ themselves. These leaders in turn are the educators and the trainers of the cadets.

An officer, who had worked in the admission committee of a military school in 1990 (registering data about the parents of the newly-accepted cadets), once said: "The most striking thing about the parents was that the majority of the spouses had about the same age. A substantial percent of the mothers had jobs, too". Those people were the parents of 15-year-old sons. They were in their mid-thirties and early forties. In the previous generations, husbands were older than their wives and the wives generally had no jobs. Those parents also represented the lower-middle classes of the big cities. Tütengil says that in contrast to developed countries, the armies of the less developed countries originate from those layers and classes who advocate for the betterment of masses. Nesin ${ }^{4}$ puts it more explicitly: "We, the former cadets (coming from Selimiye Military Junior High school) were mostly sons of poor families of big cities like İstanbul, Ankara and İzmir. Some came from small towns but were yet adapted to İstanbul life-style. When we entered the Military High school (from the Military Junior High school) quite a number of rural boys came to join us"(Years of 1930-31). More specific information is to be found in a military school's own publication: Fathers of our cadets are mostly government officials/clerks $(40.9 \%)$. The second big representative layer is that of the labors (23.2\%). $63.7 \%$ of our cadets had completed their junior high school years in province centers (including the three biggest cities). $33.1 \%$ of our cadets had completed their junior-highschool years in the country/rural areas. ${ }^{5}$

\section{Being a cadet involves a sort of initiation}

It is known that soldiers (as well as para-military people like policemen, firemen etc.) enjoy a good comradeship, which is usually absent among civilian milieu. The reason for such strong solidarity and comradeship can be explained by the initiation they go through. Though in the literal meaning initiation occurs only in primitive native tribes, in a figurative sense, hardships of the military and similar environments are substitutes for a modern version of an initiation rite. "Initiation represents 'any single dramatic ceremonial observance'; it is a 'rite de passage': Our society gives little formal recognition of the physiological and social changes a boy undergoes at puberty. He may be teased a little when his voice changes [breaks] or when he shaves for the first time. Changes in his social status from childhood are marked by a number of minor events [only]... Neither physiologically, socially nor legally is there a clear demarcation between boyhood and manhood in our society". ${ }^{6}$

"Members of fraternal and sororal organizations have long

$2^{*}$ Formerly chosen privates were trained as drivers. The preference was given to horse-carriage drivers for their better adaptability to traffic. Now an abundance of drivers come to service. Similarly, in former days dumb conscripts of course young men with IQ levels below a certain limit, are exempt from the service just like physically unfit men with little or no education were so timid that they were unable to defend their rights vis-à-vis fellow conscripts.

Then the army developed a very good procedure for the protection of such men. A company commander would usually charge such a soldier to the supervision of a smart soldier, as if the man were just a part of the equipment. The smart soldier then would become responsible for this "consignment" and protect his interests just like maintaining his own rifle, bayonet and other belongings in good order. believed that the allegiance (loyalty) of a new member would be more secure if his indoctrination included some sort of painful or at least uncomfortable form of initiation: Wearing silly clothes, scrubbing the floor of the fraternity house with a toothbrush, paying a large initiation fee, undergoing painful paddling (walking barefoot) and so forth. In a similar vein, psychiatrists have also contended that their high fees serve, in part, to make the therapeutic relationship more important to the patient" "Even in a football game an easy victory can taste vinegar, whereas a victory gained by sweat and energy might be more gratifying for the team! An officer who had worked at Çankırı PettyOfficer Preparatory School ${ }^{\left(3^{*}\right)}$ used to say: "I like my Petty-Officer cadets better than my former military lycée (a school for the wouldbe officers) cadets. When I encounter one of my former cadets from Cankırı I always stop to talk with him for a considerable time, five to ten minutes, maybe. When I worked in a military lycée, I was in a big city. But in Çankırı we were, in a sense, like prison-mates going through a provincial deprivation all together for a number of years!" Here, we can see a trace of the idea of initiation (rites of passage/ Übergangsriten), indeed.

Common hardships collectively experienced may invoke a fantastical identification of inner groups. An infantry major named Haluk spoke (June 15, 1999) as follows: "When I was the company commander in a recruit training unit, one night I was told that a firstgrade corporal awfully beat a few recruits. After the beating they had psychological conversion fits with rigid limbs, tremors of muscles and all those symptoms! The strange thing was that about half of the company soon had the same symptoms in the wards, as if they got beaten themselves! That was a busy night; with an ambulance car commuting between the unit and the state hospital in the city (the military infirmary did not suffice us)". What is even more interesting is that a comradeship feeling connecting different seniority circles can also be achieved likewise.

\section{Their own values and inferences}

Within the military; the new recruits (novices), the experienced privates (those who have left behind the basic-training season), reserve officers, military students (cadets) all have their own worlds with their own popular subculture, slang, jokes and informal value understandings. Some informal aspects of seniority can be observed to come into play among military high-school students. There different grades are separated in different buildings (and thus different classrooms, dormitories and dining facilities). Different grades (like Lycée one classes and Lycée two classes, for instance) normally have no reason to associate with one another. But on occasion some interaction may occur.

Here is an interesting case story: About two decades ago; a cadet with a very stern, serious facial expression and naturally penetrating looks used to cause irritation to higher grades and got beaten by them occasionally for his "filthy stares". Again, about a decade ago, a

$3^{*}$ Formerly chosen privates were trained as drivers. The preference was given to horse-carriage drivers for their better adaptability to traffic. Now an abundance of drivers come to service. Similarly in former days dumb conscripts of course young men with IQ levels below a certain limit, are exempt from the service just like physically unfit men with little or no education were so timid that they were unable to defend their rights vis-à-vis fellow conscripts.

Then the army developed a very good procedure for the protection of such men. A company commander would usually charge such a soldier to the supervision of a smart soldier, as if the man were just a part of the equipment. The smart soldier then would become responsible for this "consignment" and protect his interests just like maintaining his own rifle, bayonet and other belongings in good order. 
military high-school cadet discovered that a cadet from a lower class was secretly wearing a golden chain on his neck (which is forbidden). He confiscated this chain, assuming the lower cadet would not report it to the officers. The lower cadet did, admitting his own violation of regulations and risking his share of the penalty, much wilder than that of the upper class cadet, of course. Confiscating a golden chain was a felony compared to the offence of wearing it. A more common practice is some upper class members' confiscation of cigarettes (also prohibited) from lower classes and (secretly) smoking them in toilets (Figure 2).

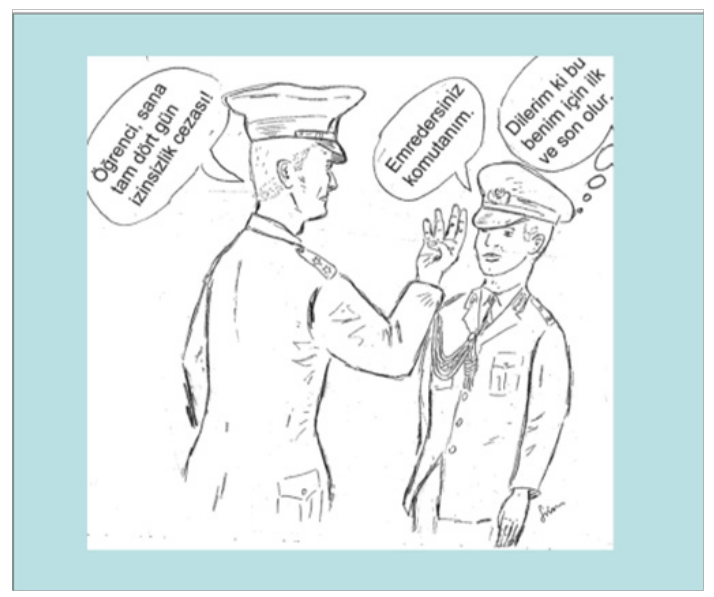

Figure 2 A Cadet Getting Punished by a Superior Officer, Cadet, 4 days of imprisonment-Yes Sir ! (I hope this will be the first and the last penalty).

In mid-1990s one of the favorite riddles of the cadets in the PettyOfficer Preparatory School in the city of Çankırı was only accidentally discovered by the eavesdropping of an officer and made known to other teachers as a popular joke. The riddle was based on a thenpopular advertisement for a "winged" hygienic band (a certain brand of a sanitary napkin against menstruation): "It has a honeycomb but no honey; it has wings but can't fly (so what is it?)"

In 1992 the first female cadets were admitted to the military Academies. In the Land Forces Academy soon special words and phrases were coined and added to the cadet-jargon. In this context "harp-iş" (literally "war-work") came to designate a female-cadet, while "harp-it" (literally "war-dog") came to designate a male-cadet. The word "jaws" (probably coined after a famous movie about sharks) came to mean a "horny" male-cadet who wants to woe or court or win the attention of a particular female-cadet, while "jawslamak" (here we have an English root combined with the Turkish infinitive suffix, the combination literally meaning "to go after a prey just as a shark would do so") is the related grammatical adverb form.

In a military lycée in 1990 a certain cadet was designated as the special-spy of a harsh battalion commander (in those schools, teachers do academic teaching work while company, battalion etc. organizations deal with disciplinary activities). He often got beaten by his fellow-cadets in the wards and officers on duty had a hard time securing his protection. The famous writer the late Aziz Nesin, a graduate of the Military Lycée in Istanbul, in his posthumous serial in a newspaper talks about the questionnaire-diaries of the cadets in his time: The questionnaire-diaries used to serve as a means of flirting with female students (in other lycés). I kept no such notebooks. But many girls used to send theirs for me to fill in because my answers were humorous and well-liked. Since my class-mates could not write such meaningful witty things, they sometimes made me write them for their sake (Figures 3-5).

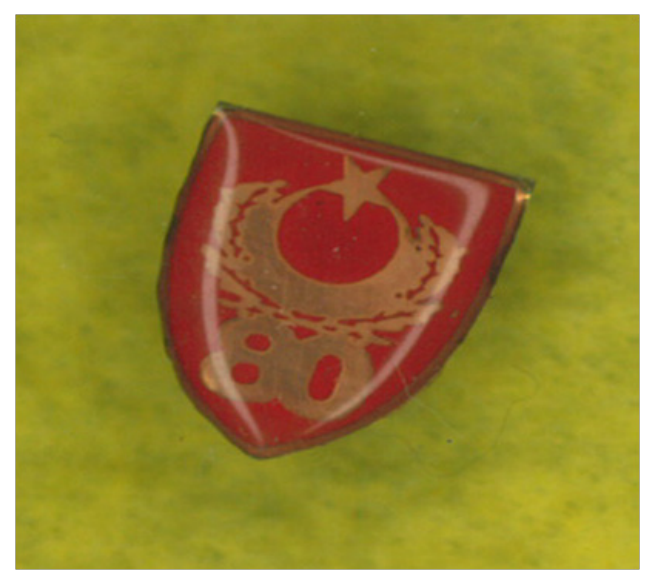

Figure 3 A Rosette of the War College in Commoration of the 1980-Graduates.

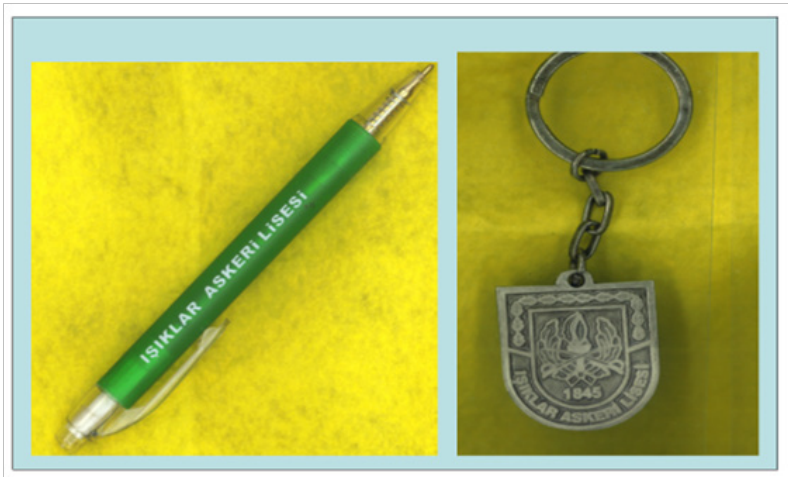

Figure 4 A Pen and a Key-Chain from the Canteen of a Military Lycée in Bursa.

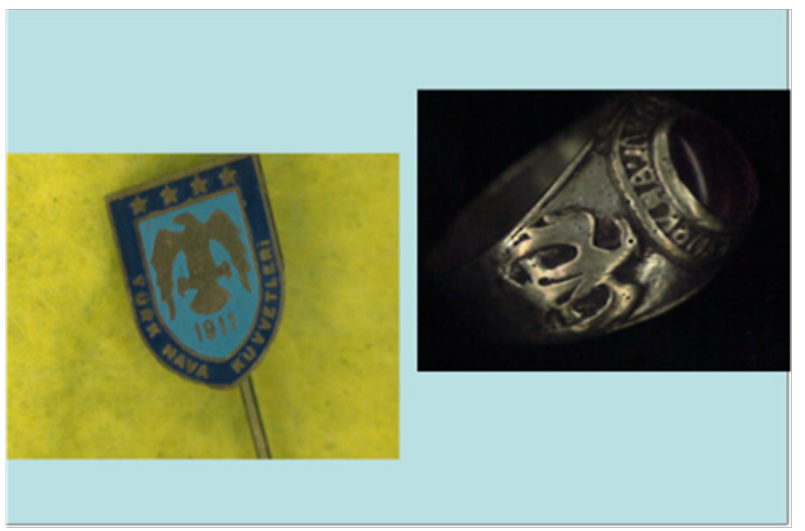

Figure $\mathbf{5}$ The Air Force War College is located in Istanbul.

Thus, I used to assume the role of Cyrano de Bergerac ${ }^{\left(4^{*}\right)}$ (Nesin goes on to say that a collection of such notebooks from various schools and years, if preserved and published, could have been a treasure for Turkey's social history. Keeping such notebooks was

${ }^{4 *}$ Edmond Rostand's unforgettable character. The French knight Cyrano had an ugly face (a big nose) but a noble heart. He wrote love ballads to a beautiful and eloquent girl from the mouth of his friend Christin, who was handsome but thickheaded. Christin used this poetry to win the heart of the girl. The irony was that Cyrano himself was secretly in love for this same girl! 
officially forbidden for the cadets). The searches were usually carried out by the first lieutenants. Mostly Capon Ethem (Japenese Ethem) and Leb Tahsin (Lip Tahsin) used to search us. The former had an oriental look and slanting eyes like me so we used to call him Capon Ethem. Leb Tahsin's lips were at least triplicate of normal lips so we used to call him Leb Tahsin ${ }^{8}$ (Here we can also see that officers were attributed nick-names, which is also a forbidden practice). The author also mentions about the horse-playing kind of jokes popular among cadets. In spite of all the efforts of the administration to establish complete rapport with the cadets, they prefer to stay aloof from the officers as if they were members of a different cast (Figure 6).

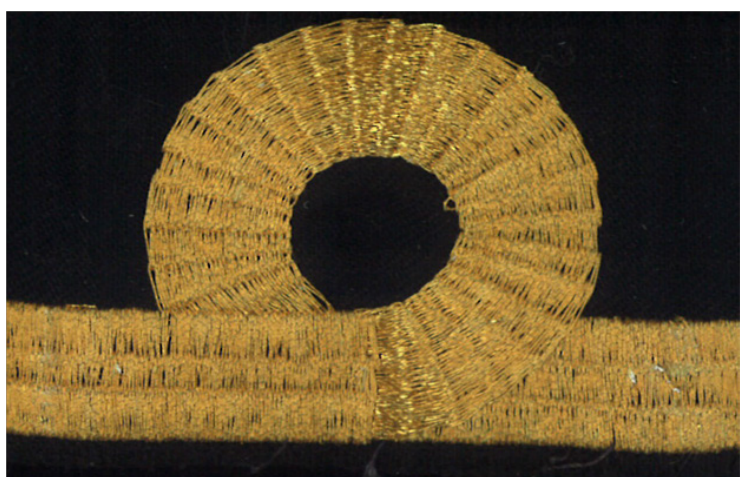

Figure 6 Navy-Lieutenant rank "in Wait" of the NavalWar College graduates.

As a case story, we can look at the following meeting held in May 5, 1997 by The Leadership Research Evaluation and Development Center (a unit established in January 1995) of The Land Forces Military Academy. A total of 93 cadets (31 freshmen, 29 sophomores and 33 juniors) were assembled in a lecture saloon and handed out questionnaire forms to be filled in.

But much more importantly, to warm them up and to urge them to give sincere answers, the senior officer (the head of this center) first had an informal talk with them in a relaxed climate and inquired into their commonly encountered difficulties. Some cadets then emphasized the lack of trust between them and the officers. Cadet U said the following: "I think the reason for the lack of confidence is insufficient communication. When they want to make us do something, they prefer punishment rather than incitement and encouragement. This continues because our encounters with the officers take place under inconvenient circumstances. Afraid we are! We do not expect remedies for our problems! This further compels them to distrust us. If I want to call in sick one day before the tactical training, my officer will assume I am goldbricking". On the same occasion Cadet I. said the following: "In our army an understanding prevails which advocates the following idea: 'if you like the subordinate, then he will be spoiled; if you are severe with him, then he will keep silent and display submission'. There is an anxiousness not to give concessions! They think that authority will be damaged".

\section{Conclusion}

Cadets in schooling age constitute the would-be chain of command of future times. For the army, they are precious beings representing times ahead. Accordingly, no efforts and no expenses are spared for their preparation. Nevertheless, their pretty humble social background, which itself is subject to change with times is one factor beyond control of officials. The strong subculture and inner solidarity reinforced by a we-feeling, which itself is rooted on initiation rituals is still another factor not to be determined by the official authority (Figure 7).

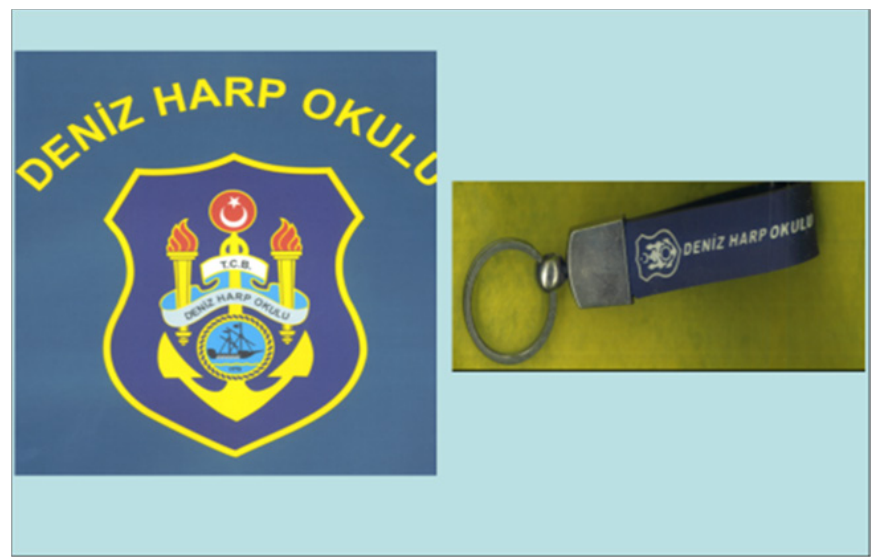

Figure 7 The Logo \& a Key-Chain of the Naval War College.

\section{Acknowledgements}

None.

\section{Conflict of interest}

Author declares that there is no conflict of interest.

\section{References}

1. Tütengil CO. Az Gelişmenin Sosyolojisi (Sociology of Underdevelopment). Belge Publications, Turkey; 1984.

2. Kongar E. Yirmibirinci Yüzyılda Dünya, Türkiye ve Kamuoyu. Simavi Publications, Turkey; 1992. p. 236.

3. Erkal M. Bölgelerarası Dengesizlik ve Doğu Kalkınması. Şâmil PrintHouse, Turkey; 1978. p. 129.

4. Nesin A. Ölümünün Birinci Yı1ında Asker Aziz Nesin: Askerin Yüzü Gölgeli Olur. Hürriyet Newspaper, July 08, Turkey; 1996a.

5. Anket Sonuçları.Kuleli Askeri lisesi Hazırlık Sınıfı Öğrencilerinin Sosyo-Ekonomik ve Kültürel Özellikleri. Printing Office of Kuleli Military High school, Turkey; 1987-1988.

6. Whiting JWM, Kluckhohn R, Anthony A. The Function of Male Initiation Ceremonies at Puberty. Henry Holt \& Company. USA; 1958;359-370.

7. Raven BH, RH, Rubin JZ. Social Psychology: People in Group. John Wiley \& Sons Inc, New York, USA; 1976.

8. Nesin A. Ölümünün Birinci Yılında Asker Aziz Nesin: Sadece İki Kitap Yasak Değil. Hürriyet Newspaper, July 09, Turkey; 1996b. 